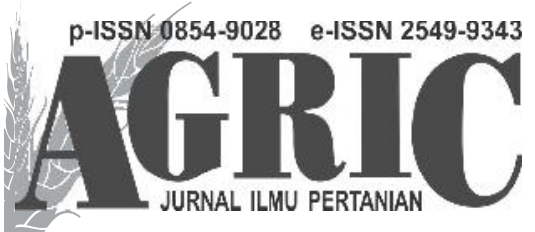

Fakultas Pertanian dan Bisnis Universitas Kristen Satya Wacana

Jl. Diponegoro 52-60 SALATIGA 50711 - Telp. 0298-321212 ext 354

email: jurnal.agric@adm.uksw.edu, website: ejournal.uksw.edu/agric

Terakreditasi Kementrian Riset, Teknologi dan Pendidikan Tinggi berdasarkan SK No 21/E/KPT/2018

PRODUKSI TANAMAN KAPAS DENGAN MENGGUNAKAN IRIGASI TETES PADA DUA TAHUN TANAM YANG BERBEDA

\title{
PRODUCTION OF COTTON PLANTS USING DRIP IRRIGATION IN TWO DIFFERENT PLANTING YEARS
}

\author{
Syahruni Thamrin ${ }^{1}$, Junaedi' ${ }^{1}$ H. Baso Darwisah ${ }^{1}$ \\ ${ }^{1}$ Jurusan Budidaya Tanaman Perkebunan \\ Politeknik Pertanian Negeri Pangkep \\ syahrunithamrin@gmail.com
}

Diterima 25 Oktober 2018, disetujui 17 Desember 2018

\begin{abstract}
Cotton plants require sufficient water availability, especially during germination and growth and dry conditions at harvest. In drip irrigation, irrigation can be adjusted to the water needs of each type of plant that varies depending on the growth phase and the type of plant. The study aims to determine the growth and production of cotton plants that use drip irrigation systems in two different planting seasons. The study was conducted for 2 (two) consecutive years, the first study: planting using drip irrigation was carried out in August 2017 and continued with the second planting in May 2018. The research was conducted in Turucinnae Village, Lamuru District, Bone Regency, South Sulawesi Province. The research was carried out in the form of field experiments in the form of a demonstration plot using an experimental design and analysis carried out to find out and explain the implementation of drip irrigation in two different planting seasons.

Vegetative growth of cotton plants that use drip irrigation in 2017 provides better results than in 2018 seen from plant height and number of leaves, while the production of cotton plants using drip irrigation in 2017 is greater than that planted in 2018 in terms of the number of bolls. Formed and weight of cotton produced.
\end{abstract}

Keywords: cotton, drip irrigation, different planting years. 


\begin{abstract}
ABSTRAK
Tanaman kapas membutuhkan persyaratan ketersediaan air yang cukup, utamanya pada saat perkecambahan dan pertumbuhan serta kondisi yang kering saat panen. Pada irigasi tetes, pengairan bisa disesuaikan dengan kebutuhan air setiap jenis tanaman yang berbeda-beda tergantung pada fase pertumbuhan dan jenis tanamannya. Penelitian bertujuan untuk mengetahui pertumbuhan dan produksi tanaman kapas yang menggunakan sistem irigasi tetes pada dua musim tanam yang berbeda. Penelitian dilakukan selama 2 (dua) tahun berturut-turut, penelitian pertama: penanaman dengan menggunakan irigasi tetes dilakukan pada bulan Agustus 2017 dan dilanjutkan penanaman kedua pada bulan Mei 2018. Penelitian dilaksanakan di Desa Turucinnae Kecamatan Lamuru Kabupaten Bone Provinsi Sulawesi Selatan. Penelitian dilakukan dalam bentuk percobaan lapangan dalam bentuk demonstrasi plot dengan menggunakan desain eksprimen dan analisis dilakukan untuk mengetahui dan menjelaskan pelaksanaan irigasi tetes pada dua musim tanam yang berbeda.

Pertumbuhan vegetatif tanaman kapas yang menggunakan irigasi tetes pada tahun 2017 memberikan hasil yang lebih baik dibandingkan tahun 2018 dilihat dari tinggi tanaman dan jumlah daun, sedangkan produksi tanaman kapas yang menggunakan irigasi tetes pada tahun 2017 lebih besar dibanding yang ditanam tahun 2018 dilihat dari segi jumlah boll yang terbentuk dan berat kapas yang diproduksi.
\end{abstract}

Kata kunci: kapas, irigasi tetes, tahun tanam berbeda.

\section{PENDAHULUAN}

Tanaman kapas (Gossypium hirsutum L.) merupakan tanaman penghasil serat yang merupakan bahan baku utama industri tekstil dan produk tekstil dari serat alam. Produksi serat kapas dalam negeri hanya berkisar 1.600-2.500 ton (kurang dari $0,5 \%$ kebutuhan nasional). Sebagian besar diperoleh melalui impor. Nilai ini kian merosot tajam, terlihat pada tahun 2008 produksi kapas masih berada di level 3.800 ton, pada tahun 2013 turun drastis pada kisaran 2.500-an ton yang berarti selama 6 tahun, yaitu sejak 2008 hingga 2013, produksi kapas turun sekitar $33,69 \%$. Turunnya produksi disebabkan turunnya produktivitas tanaman dan luas areal penanaman. Pada tahun 2008 produktivitas tanaman petani masih pada kisaran 4,5 kuintal per ha, namun pada tahun 2013 produktivitasnya menjadi 3,1 kuintal per ha. Pengembangan kapas seluas 3.300 ha dalam rangka pemenuhan konsumsi dalam negeri khususnya penanaman kapas seluas 3.130 ha dan pembanguan kebun induk seluas 170 ha (Ditjenbun, 2013).
Guna mendukung pengembangan kapas di Indonesia maka pemerintah melalui program akselerasi tahun 2011 menargetkan pengembangan kapas dari masing-masing provinsi wilayah pengembangan kapas seluas 15.900 ha, mencakup; Jateng 1.000 ha, Jatim 2.050 ha, DIY 750 ha, Bali 800 ha, NTB 800 ha dan NTT 3.500 ha serta Sulsel 7.000 ha (Ditjenbun, 2010). Di Sulawesi Selatan, kapas merupakan prioritas kedua dalam pembangunan sub sektor perkebunan setelah kakao. Sentra pengembangannya meliputi Kabupaten Gowa, Takalar, Jeneponto, Bantaeng, Bulukumba, Bone, Soppeng, dan Wajo (Junaedi, 2016).

Kapas merupakan tanaman sub tropis yang dapat tumbuh dengan baik di daerah tropis. Faktor lingkungan merupakan salah satu faktor pembatas dalam budidaya tanaman kapas yang harus diperhatikan. Tanaman kapas membutuhkan persyaratan ketersediaan air yang cukup, terutama untuk perkecambahan dan 
pertumbuhan serta kondisi kering saat panen (Hearn dan Fitt, 1992). Kebutuhan air akan disesuaikan dengan jenis dan umur tanaman. Produktivitas tanaman tidak maksimal bila keadaan lingkungan tidak sesuai, meskipun penerapan teknologi telah diupayakan. Untuk itu perlu diperhatikan keadaan tanah dan iklim serta ketersediaan air untuk menunjang pertumbuhan dan perkembangan tanaman (Dewi, 2014).

Beberapa literatur menyatakan hanya sekitar $10 \%$ dari air yang diberikan yang diserap oleh akar tanaman, selebihnya (90\%) terbuang melalui perkolasi, evaporasi dan lain-lain. Pada musim kemarau, air yang tersedia sangat sedikit, sedangkan kebutuhan akan air kurang lebih sama dengan musim hujan. Untuk mengatasi kebutuhan air di masa sulit air adalah dengan menggunakan irigasi tetes. Pada irigasi tetes, pengairan bisa disesuaikan dengan kebutuhan air setiap jenis tanaman yang berbeda-beda tergantung pada fase pertumbuhan dan jenis tanamannya. Terlebih lagi kondisi pertanaman kapas khususnya di Sulawesi Selatan senantiasa terkendala dalam pemenuhan air untuk pertumbuhan dan perkembangan tanaman kapas.

Penelitian dilakukan multi tahun dimana pada tahun pertama penanaman dilakukan pada bulan Agustus 2017 dan penanaman tahun kedua dilakukan pada bulan Mei 2018. Penelitian bertujuan untuk mengetahui apakah dengan penggunaan irigasi tetes dapat meningkatkan produksi. Bagaimana pertumbuhan dan produksi tanaman kapas yang menggunakan sistem irigasi tetes pada dua musim tanam yang berbeda. Penelitian ini diharapkan bermanfaat untuk mengatasi persoalan kekurangan air pada tanaman kapas hingga mampu mencapai produksi yang optimal.

\section{METODE PENELITIAN}

\section{Waktu dan Tempat}

Penelitian dilakukan selama 2 (dua) tahun berturut-turut, penelitian pertama: penanaman dilakukan pada bulan Agustus 2017 dan dilanjutkan penanaman kedua pada bulan Mei 2018. Penelitian dilaksanakan di Desa Turucinnae Kecamatan Lamuru Kabupaten Bone Provinsi Sulawesi Selatan. Penelitian dilakukan dalam bentuk percobaan lapangan dalam bentuk demonstrasi plot dengan menggunakan desain eksprimen dan analisis dilakukan untuk mengetahui dan menjelaskan pelaksanaan irigasi tetes pada dua musim tanam yang berbeda.

\section{Alat dan Bahan}

Alat yang digunakan dalam penelitian ini adalah jaringan irigasi tetes, bak penampungan, pompa air, ember, gelas plastik, stopwatch, timer, cangkul, lem pipa dan gergaji besi. Sedangkan bahan yang digunakan adalah benih kapas Kanesia 10, pupuk dan insektisida.

Pelaksanaan penelitian meliputi beberapa tahap, yaitu:

(a) persiapan dan pengukuran media tanam,

(b) persiapan alat dan bahan,

(c) perancangan sistem irigasi tetes,

(d) instalasi jaringan irigasi tetes,

(e) pengujian emitter,

(f) uji kinerja jaringan irigasi tetes pada tanaman, dan

(g) pengolahan data

Parameter pengamatan meliputi: Pengamatan terhadap pertumbuhan tanaman kapas, yaitu tinggi tanaman dan jumlah daun, dan pengamatan terhadap produksi tanaman kapas yaitu jumlah boll dan berat kapas. Waktu pengamatan setiap hari untuk menghitungkebutuhan air dan kondisi 
pertanaman dan pengamatan pertumbuhan dilakukan 7 hari sekali, di mulai pada minggu IV yang diulang setiap minggu. Sedangkan produksi serat (berat kapas) dihitung pada akhir panen.

Pengumpulan data pada penelitian ini diperoleh melalui observasi langsung berdasarkan perlakuan yang diberikan, selanjutnya dilakukan analisis deskriptif untuk memberikan gambaran terhadap data dan informasi yang telah diperoleh.

\section{HASIL DAN PEMBAHASAN}

\section{Tinggi Tanaman Kapas}

Pertambahan tinggi tanaman kapas pada dua tahun yang berbeda dapat dilihat pada Gambar 1 dan Gambar 2. Gambar 1 memperlihatkan pertambahan tinggi tanaman kapas pada tahun 2017 dan tahun 2018 dengan menggunakan irigasi tetes. Sedangkan Gambar 2 memperlihatkan pertambahan tinggi tanaman kapas pada tahun 2017 dan tahun 2018 tanpa menggunakan irigasi tetes.

Pada Gambar 1 terlihat bahwa pertambahan tinggi tanaman kapas dengan menggunakan irigasi tetes pertambahannya lebih besar pada tahun 2017 dibandingkan dengan pada tahun 2018

\section{Jumlah Daun Tanaman Kapas}

Pertambahan jumlah daun tanaman kapas pada dua tahun yang berbeda dapat dilihat pada Gambar 3. Gambar 3 memperlihatkan pertambahan jumlah daun kapas yang ditanam dengan menggunakan irigasi tetes terlihat lebih baik pada tahun 2017 dibanding pada tahun 2018.

\section{Jumlah Boll Tanaman Kapas}

Jumlah boll tanaman kapas dapat dilihat pada Gambar 3. Gambar 3 memperlihatkan jumlah boll tanaman kapas yang ditanam dengan menggunakan irigasi tetes memberikan hasil yang lebih baik pada tahun 2017 dibanding pada tahun 2018.

\section{Berat Kapas}

Berat serat kapas dapat dilihat pada Gambar 4. Gambar 4 memperlihatkan bahwa berat kapas pada tahun 2017 lebih besar yaitu $2,59 \mathrm{~kg}$ dibanding tahun 2017 hanya $0,294 \mathrm{~kg}$.

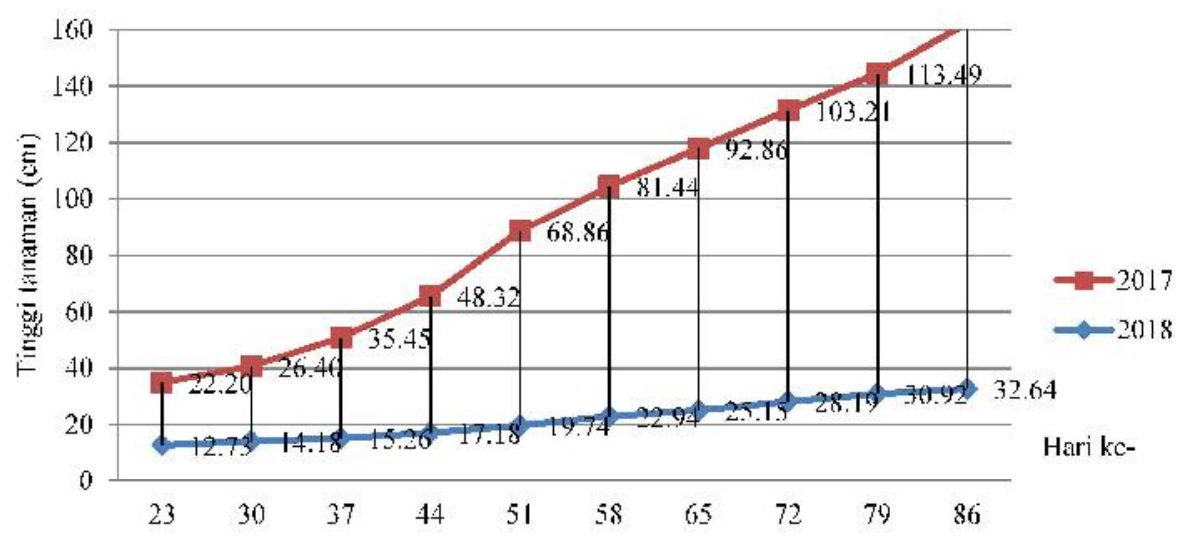

Gambar 1 Tinggi tanaman dengan menggunakan irigasi tetes 


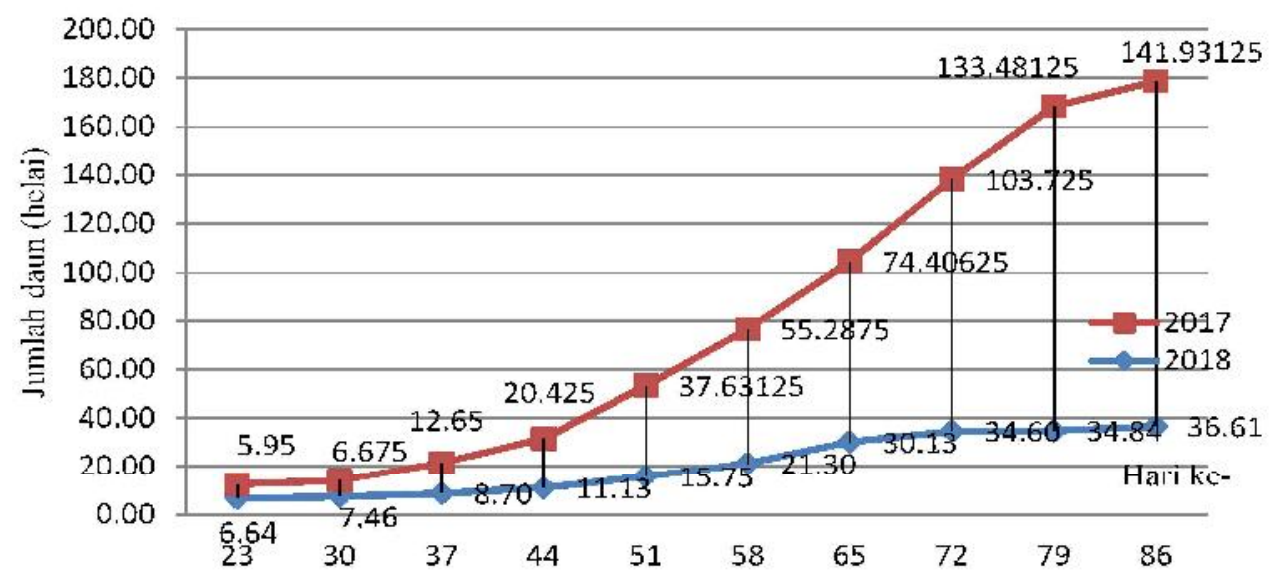

Gambar 2 Jumlah daun tanaman kapas yang menggunakan irigasi tetes

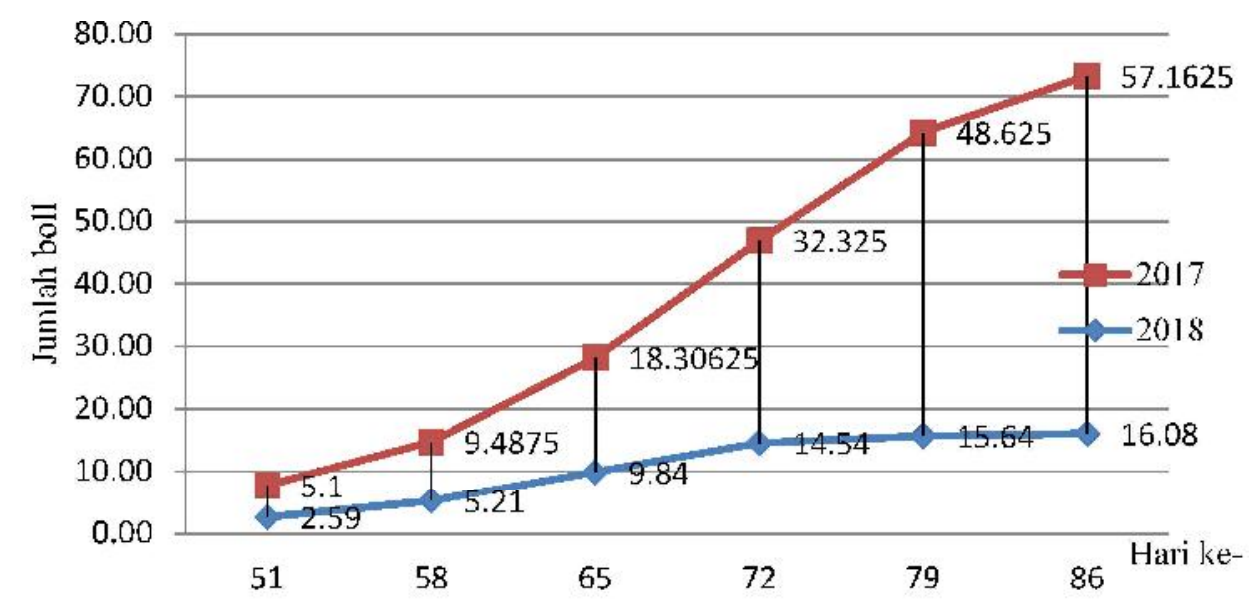

Gambar 3 Jumlah boll tanaman kapas yang menggunakan irigasi tetes

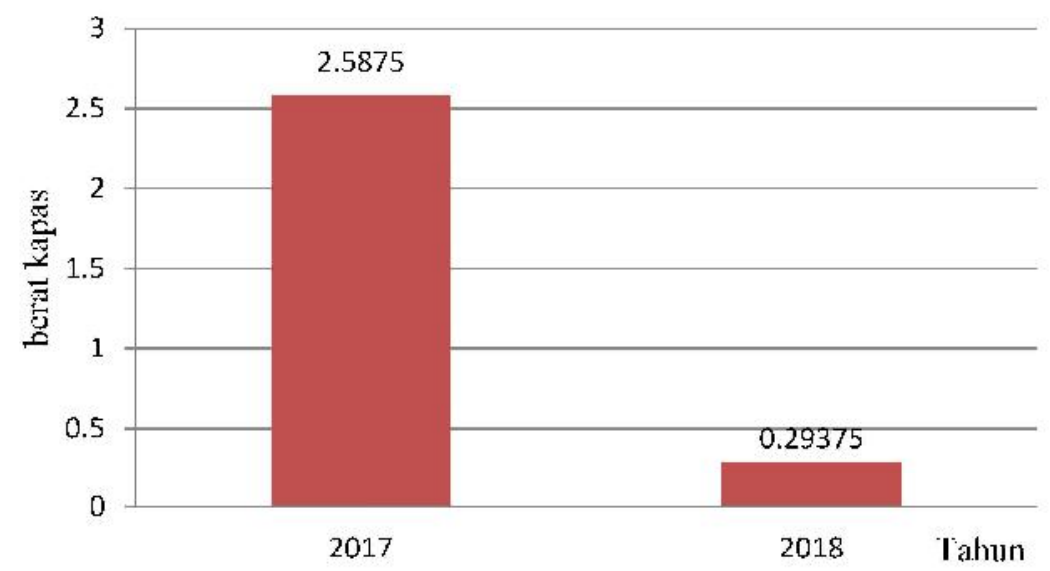

Gambar 4 Berat serat tanaman kapas 


\section{Pembahasan}

Tanaman kapas dapat tumbuh dan berkembang dengan baik bila kebutuhan akan persyaratan tumbuhnya terpenuhi. Faktor lingkungan merupakan salah satu faktor pembatas dalam budidaya tanaman kapas yang harus diperhatikan. Pengaturan waktu tanam diperlukan untuk mensiasati waktu kapan tanaman rentan atau tidak terhadap ketersediaan air di lahan selama masa pertumbuhan.

Menurut Thamrin et. al. (2017) rata-rata terjadinya perkecambahan benih kapas Kanesia pada umur 6 hari setelah tanam (hst) hingga 13 hari setelah tanam (hst). Kondisi awal ini sangat dipengaruhi oleh tekanan tanah terhadap benih saat penanaman. Namun secara keseluruhan pertumbuhan berlangsung optimal, karena kondisi tanah dalam kondisi lembab.

Berdasarkan hasil yang diperoleh terlihat bahwa pertumbuhan tanaman kapas dari segi tinggi tanaman (Gambar 1) dan jumlah daun (Gambar 2) memberikan hasil terbaik pada tahun 2017 dibandingkan dengan tahun 2018, demikian pula terhadap produksi tanaman kapas (jumlah boll dan berat kapas). Tanaman kapas yang ditanam pada tahun 2017 ditanam pada bulan Agustus, sedangkan yang ditanam pada tahun 2018 jatuh pada bulan Mei. Bulan Mei tahun 2018merupakan awal musim kemarau di daerah Turucinnae Kecamatan Lamuru Kabupaten Bone, yang berarti menanam pada bulan Mei atau menanam pada musim kemarau yang ketersediaan airnya sudah mulai berkurang. Kenyataan ini menyebabkan berkurangnya ketersediaan air dalam tanah karena menurunnya curahan dari hujan. Untuk memacu pertumbuhan kapas maka perlu tambahan air dan hara karena pada bulan Mei curah hujan sudah mulai berkurang. Berdasarkan data BKMG bulan Mei 2018 curah hujan di Kecamatan Lamuru tergolong curah hujan menengah, dengan jumlah hujan 201-300 mm. Menurut Riajaya et. al., (1989), tanaman kapas akan tumbuh baik pada daerah dengan curah hujan 500-1.600 mm selama 120 hari. Sehingga diperlukan tambahan air untuk menyempurnakan pertumbuhan dan pembentukan buah tanaman kapas. Penggunaan irigasi tetes merupakan salah satu cara untuk mengatasi kekurangan air pada tanaman sehingga kebutuhan air tanaman dapat tetap terpenuhi. Manfaat irigasi tetes antara lain ialah penghematan air, waktu, tenaga kerja, dan biaya tenaga kerja. Penghematan air karena diberikan ke tanaman sesuai dengan kebutuhan tanaman. Penyiraman dengan irigasi tetes menghemat waktu karena penyiraman dilakukan secara otomatis dengan hanya membuka kran. Penggunaan tenaga kerja menjadi berkurang karena penyiraman dilakukan secara serentak.

Curah hujan yang cukup sangat diperlukan terutama dalam periode awal, pembungaan, dan pengisian buah. Tanah-tanah dengan kemampuan memegang air yang rendah akan membutuhkan irigasi yang lebih sering dibanding tanah-tanah dengan kemampuan memegang air yang tinggi. Kebutuhan air tanaman yang paling banyak adalah pada saat perkembangan kanopi maksimum yang bersamaan dengan puncak musim kemarau. Hal tersebut menyebabkan perlunya konservasi air agar kelembaban tanah tetap terjaga.

Tidak hanya jumlah curah hujan yang berpengaruh terhadap produksi kapas, tetapi yang lebih penting adalah distribusinya selama pertumbuhan. Sebenarnya kapas masih membutuhkan air menjelang panen tetapi tidak 
menghendaki adanya hujan, berarti air harus cukup tersedia di dalam tanah (Riajaya, 2006). Kekeringan pada puncak pembungaan tanaman kapas berpotensi menurunkan hasil paling tinggi karena kuncup bunga dan buah-buah muda banyak yang gugur. Selain itu, kuncup bunga yang baru terbentuk tidak akan mempunyai waktu yang cukup untuk menjadi buah (Grimes danEl-Zik, 1990). Hal ini terlihat pada Gambar3, jumlah boll yang dihasilkan pada tahun 2018 lebih sedikit dibanding jumlah boll pada tahun 2017 sehingga berat kapas pun lebih sedikit pada tahun 2018 dibanding tahun 2017. Hal ini sejalan dengan penelitian yang dilakukan Riajaya (2006) di Lampung Jawa Timur, bahwa pola hujan yang berlangsung mulai November hingga April maka penentuan tanam baik padi maupun kapas sesudahnya harus disesuaikan. Kebiasaan petani setempat memelihara kapas setelah kedelai dipanen sehingga menyebabkan umur kapas bertambah panjang dan waktu panen kapas semakin lama sehingga dengan semakin bertambah panjangnya umur tanaman kapas, maka kepastian akan ketersediaan air menjadi sangat penting. Sebagai tanaman kedua setelah padi atau palawija menyebabkan waktu tanam kapas sering mundur, akibatnya sering berhadapan dengan kondisi kekeringan yang menyebabkan turunnya produksi karena meningkatnya serangan hama.

Berbeda dengan penanaman yang dilakukan pada bulan Agustus tahun 2017, pertumbuhan dan produksi kapas yang dihasilkan jauh lebih baik. Tanaman kapas ditanam pada akhir musim hujan sehingga kebutuhan air tanaman masih terpenuhi dari airyang masih tersimpan di dalam tanah. Selain itu dengan penggunaan irigasi tetes maka ketersediaan air untul pertumbuhan dan perkembangan tanaman masih terpenuhi dari suplay air rigasi tetes dan dengan irigasi tetes dapat dilakukan pengaturan pemberian air yang sesuai dengan kebutuhan tanaman pada setiap fasenya. Menurut Fitriana et. al., (2015) sistem irigasi tetes mempunyai cara pengontrolan yang baik sejak air dialirkan sampai diserap tanaman. Di samping itu sistem irigasi tetes mengurangi proses penguapan (evaporasi), di mana nutrisi dapat langsung diberikan ke tanaman melalui irigasi. Air menjadi media pengangkut nutrisi/ hara dari tanah ke seluruh bagian tanaman.

Kebutuhan air yang terbesar bagi tanaman kapas adalah pada fase pembentukan bunga dan buah (umur 8-15 minggu) (Rejekiningrum et. al., 2007). Produksi serat kapas $95 \%$ berasal dari buah-buah yang terbentuk pada minggu ke 8 sampai 12 setelah tanam. Pada periode tersebut tanaman kapas sangat rentan terhadap kekurangan air, karena akan menyebabkan tanaman menggugurkan kuncup bunga, bunga dan buah muda. Hal ini berhubungan dengan sifat fisiologis tanaman, dalam menjaga keseimbangan agar tetap dapat bertahan hidup melewati periode kering (Krieg, 1989). Selain rentan terhadap kekurangan air tanaman kapas pada periode ini juga sangat rentan terhadap kelebihan air yang mempunyai pengaruh sama terhadap pengurangan produksi (Doorenbos and Kassam, 1979). Sehingga dengan penggunaan irigasi tetes ini dapat diatur penggunaan dan pemberian air bagi tanaman sesuai dengan kebutuhan tanaman kapas dengan mempertimbangkan keadaan cuaca utamanya curah hujan.

\section{KESIMPULAN}

Berdasarkan hasil yang diperoleh terlihat bahwa dengan penggunaan irigasi tetes pada tahun tanam yang berbeda memberikan hasil yang berbeda, pertumbuhan tanaman kapas yang diamati dari segi tinggi tanaman dan jumlah 
daun memberikan hasil yang lebih baik pada tahun 2017 daripada tahun 2018. Demikian pula untuk produksi tanaman kapas dalam hal ini jumlah boll dan berat kapas memberikan hasil yang lebih baik pada tahun tanam 2017 dibanding tahun 2018.

\section{UCAPAN TERIMA KASIH}

Ucapan terima kasih kepada Kementerian Ristekdikti melalui Direktorat Penelitian dan Pengabdian pada skim penelitian Strategis Nasional.

\section{DAFTAR PUSTAKA}

Dewi, E. S. 2014. AspekAgronomi Tanaman Kapas. Penerbit. Dapur Buku, Jakarta.

Direktorat Jenderal Perkebunan. 2010. Akselerasi Pengembangan Kapas. Pertemuan Koordinasi Persiapan Pelaksanaan Pengembangan Tanaman Serat Tahun 2010. Departemen Pertanian. Jakarta.

Doorenbos. J. and A.H. Kassam. 1979. Yield Response to Water. FAO Irrigation and Drainage Paper no 33. 193p.

Fitriana, N., F, D. Arianti dan M. N. Semipermas. 2015. Inovasi Hortikultura. Pengungkit Peningkatan Pendapatan Rakyat. Badan Penelitian dan Pengembangan Pertanian Kementerian Pertanian IAAR Press. Jakarta.

Grimes, D.W. and K.M. El-Zik. 1990. Cotton. In Stewart, B.A. and D.R. Nielson (Eds.). Irrigation of Agricultural Crops. Agronomy. No. 30. ASA. CSSA. SSSA. USA. P. 741-774.
Hearn, A.B. and G.P. Fitt. 1992. Cotton cropping systems. In Ecosystems of the world: Field Crop Ecosystems (Pearson, C.J. ed.). Elsevier. Amsterdam. London. New York. Tokyo. P. 85-142.

Junaedi. 2016. Pengembangan Kapas Rakyat di Sulawesi Selatan. Kajian Terhadap Efisiensi Produksi dan Daya Saing. CV. Mujahid Press, Bandung.

Krieg, D. R. 1989. Nitrogen and Water Management Means Top Cotton Yields. Solutions January 1989.

Rejekiningrum, P, Y. Apriyana, dan F. Ramadhani. 2005. Pendayagunaan Sumberdaya Air Untuk Pengembangan Kapas di Sulawesi Selatan. Laporan Akhir. Kerjasama Balai Penelitian Agroklimat dan Hidrologi dengan Direktorat Tanaman Semusim, Direktorat Jenderal Bina Produksi Perkebunan. Balitklimat, Bogor.

Riajaya, P.D., M.Yusron, dan M. Cholid. 1998. Strategi Pengelolaan Air Kapas di Lahan Sawah. Prosiding Diskusi Kapas Nasional. Balittas. P.159-166.

Riajaya, P.D. 2006. Sebaran Curah Hujan Sebagai Dasar Penetapan Waktu Tanam Pada Lahan Sawah Sesudah Padi di Lamongan, Jawa Timur. Perspektif Volume 5 no 1. Juni 2006: 26-35.

Thamrin, S., Budiman, Baso Darwisah, Junaedi. 2018. Penerapan Drip Irrigation Pada Pertumbuhan Tanaman Kapas (Gossipium sp.). Agric Vol. 29 No 2 Desember 2017:113-120. e-ISSN 2549-9343. 